\title{
Adenovirus-mediated siRNA targeting TNF- $\alpha$ and overexpression of bone morphogenetic protein-2 promotes early osteoblast differentiation on a cell model of Ti particle-induced inflammatory response in vitro
}

\author{
H.H. Guo ${ }^{1}$, C.C. $\mathrm{Yu}^{1}$, S.X. Sun ${ }^{1}$, X.J. $\mathrm{Ma}^{2}$, X.C. Yang ${ }^{1}$, K.N. Sun ${ }^{1}$ and Q.H. Jin \\ ${ }^{1}$ Department of Orthopedic Surgery, Affiliated Hospital of Ningxia Medical University, Yinchuan, China \\ ${ }^{2}$ Department of Orthopedic Surgery, Ningxia Medical Autonomous Region of the First People's Hospital, Yinchuan, China
}

\begin{abstract}
Wear particles are phagocytosed by macrophages and other inflammatory cells, resulting in cellular activation and release of proinflammatory factors, which cause periprosthetic osteolysis and subsequent aseptic loosening, the most common causes of total joint arthroplasty failure. During this pathological process, tumor necrosis factor-alpha (TNF- $\alpha$ ) plays an important role in wear-particle-induced osteolysis. In this study, recombination adenovirus (Ad) vectors carrying both target genes [TNF- $\alpha$ small interfering RNA (TNF- $\alpha$-siRNA) and bone morphogenetic protein 2 (BMP-2)] were synthesized and transfected into RAW264.7 macrophages and pro-osteoblastic MC3T3-E1 cells, respectively. The target gene BMP-2, expressed on pro-osteoblastic MC3T3-E1 cells and silenced by the TNF- $\alpha$ gene on cells, was treated with titanium (Ti) particles that were assessed by realtime PCR and Western blot. We showed that recombinant adenovirus (Ad-siTNF $\alpha$-BMP-2) can induce osteoblast differentiation when treated with conditioned medium (CM) containing RAW264.7 macrophages challenged with a combination of Ti particles and Ad-siTNF $\alpha$-BMP-2 (Ti-ad CM) assessed by alkaline phosphatase activity. The receptor activator of nuclear factor- $\mathrm{\kappa B}$ ligand was downregulated in pro-osteoblastic MC3T3-E1 cells treated with Ti-ad CM in comparison with conditioned medium of RAW264.7 macrophages challenged with Ti particles (Ti CM). We suggest that Ad-siTNF $\alpha$-BMP-2 induced osteoblast differentiation and inhibited osteoclastogenesis on a cell model of a Ti particle-induced inflammatory response, which may provide a novel approach for the treatment of periprosthetic osteolysis.
\end{abstract}

Key words: TNF- $\alpha$; BMP-2; Small interfering RNA; Titanium particles; Osteolysis

\section{Introduction}

Titanium (Ti) components have become widely used for joint replacement, and have excellent corrosion resistance, biocompatibility and a high resistance-toweight ratio. However, wear debris that forms at prosthetic joint articulations, modular interfaces, and nonarticulating interfaces $(1,2)$ is the main reason for prosthesis failure (3-5). In this pathological process, activated macrophages/ monocytes respond to Ti particles, releasing proinflammatory mediators and cytokines including tumor necrosis factor alpha (TNF- $\alpha$ ), interleukin (IL)-6, and IL-1 $\beta$ in vitro (6-8) and are present in periprosthetic soft tissue in vivo (9).
Research suggests that the biological response to wear particles at the bone-implant interface is the main cause of aseptic loosening and osteolysis $(10,11)$. The proinflammatory cytokines are thought to cause an imbalance in bone metabolism, favoring bone resorption via the induction of the receptor activator of nuclear factor- $\kappa \mathrm{B}$ ligand (RANKL) and macrophage colony-stimulating factor (MCSF) in osteoblasts (12-14) and by blocking bone formation via inhibition of osteoblast differentiation (15-17).

Bone is a dynamic tissue that is constantly formed by osteoblasts and resorbed by osteoclasts, which maintain a 
dynamic balance on the principle that the amount of bone destroyed by osteoclasts is equal to the amount of bone formed by osteoblasts. Proinflammatory cytokines such as $\mathrm{IL}-1 \beta$ and TNF- $\alpha$ can disturb the balance of bone metabolism by inhibiting bone formation and increasing bone resorption, leading to a loss of bone stock. The reduced bone stock also contributes to periprosthetic osteolysis. On the basis of these considerations, we concluded that these proinflammatory cytokines would provide a promising therapeutic target for the treatment of periprosthetic osteolysis.

Osteoblasts not only play a central role in bone formation by synthesizing several bone matrix proteins, but regulate osteoclast maturation through expression of soluble factors RANKL and M-CSF, resulting in bone resorption. Osteoblastic differentiation could inhibit osteoclast formation via downregulation of RANKL expression $(18,19)$ and upregulation of osteoprotegerin (OPG) expression (20).

Bone morphogenetic protein 2 (BMP-2) plays an important role in regulating osteoblast differentiation and subsequent bone formation (21-23). However, TNF- $\alpha$ can restrain BMP-2 signaling in osteoblastic differentiation (24-26). Downregulating TNF- $\alpha$ expression in activated macrophages in response to Ti particles, while simultaneously upregulating BMP-2 expression to promote osteoblast differentiation, is expected to be effective in the treatment or prevention of periprosthetic ostelysis.

Therefore, we used gene therapy to prevent and/or treat aseptic loosening of prosthetic joints by constructing an adenovirus (Ad)-mediated small interfering RNA (siRNA) targeting TNF- $\alpha$ and, at the same time, overexpression of BMP-2 (Ad-siTNF $\alpha$-BMP-2). We determined whether the recombinant adenovirus (Ad-siTNF $\alpha$-BMP-2) could inhibit the expression of TNF- $\alpha$ in RAW264.7 cells when cultured with $\mathrm{Ti}$ particles. We also investigated the effects of Ad-TNF- $\alpha$-siRNA-BMP-2 on osteoblastic MC3T3-E1 cells to confirm differentiation in conditioned culture media (CM).

\section{Material and Methods}

\section{Preparation of $\mathrm{Ti}$ particles}

Commercially pure $\mathrm{Ti}$ particles were obtained from Zimmer Company (USA); $90 \%$ of the Ti particles were $<10 \mathrm{~mm}$ in diameter. The Ti particles were prepared as previously described (27). The particles were sterilized at $180^{\circ} \mathrm{C}$ for $6 \mathrm{~h}$, followed by treating with $70 \%$ ethanol for $48 \mathrm{~h}$ to remove endotoxin. The particle endotoxin level in this study was lower than $0.1 \mathrm{EU} / \mathrm{mL}$, as determined using a commercial detection kit (E-Toxate; Sigma, USA). Ti particles were sonicated and vortexed before treatment.

\section{Construction of adenovirus-expressing TNF $\alpha$-siRNA- BMP-2}

Full-length BMP-2 cDNA expressed in pCDNA3.1 vector (Kpnl and $\mathrm{Xbal}$ sites) was cloned into a pAd5E3-CMV shuttle plasmid using Clal and Spel sites; the plasmids were then amplified by transfection into $\mathrm{DH} 5 \alpha$ cells, and positive clones (pAd5E3-CMV-mBMP-2-pA) were selected and confirmed by DNA miniprep and Pacl digestion. To construct the pAd5E3-CMV-mBMP-2 backbone, pAd5E3CMV-mBMP-2-pA was linearized with $P a c l$ digestion and subsequently cotransformed into BJ5183 cells with a pAd5 backbone using Swal sites (28). Plasmids were amplified by transforming into $\mathrm{DH} 5 \alpha$ cells followed by DNA maxiprep. To construct adenoviral vectors expressing both BMP-2 and TNF- $\alpha$-siRNA, pAd5E1-hU6 TNF $\alpha$ siRNA-CMVeGFP were linearized with $\mathrm{Pacl}$ digestion and subsequently cotransformed into HEK293 cells with a linearized pAd5E3-CMV-mBMP-2 backbone. Adenoviral vectors were purified with three density gradients of $\mathrm{CsCl}$ dialyzed with viral titers, determined by absorbance and standard plaque assays as described previously (29).

\section{Cell culture}

The murine macrophage/monocyte cell line RAW264.7 (BH-AC71; ATCC, USA) was maintained at $37^{\circ} \mathrm{C}$ and $5 \%$ $\mathrm{CO}_{2}$ in Dulbecco's modified Eagle's medium (DMEM; Sigma) containing 10\% FBS (Hyclone, USA), $100 \mathrm{U} / \mathrm{mL}$ penicillin, and $100 \mathrm{U} / \mathrm{mL}$ streptomycin. The murine osteoblastic cell line MC3T3-E1 (ATCC) was cultured in $\alpha$-minimum essential medium (Sigma) supplemented with $10 \% \mathrm{FBS}, 100 \mathrm{U} / \mathrm{mL}$ penicillin, and $100 \mathrm{U} / \mathrm{mL}$ streptomycin at $37^{\circ} \mathrm{C}$ and $5 \% \mathrm{CO}_{2}$.

\section{Collection of conditioned media}

RAW264.7 cells were plated on 24-well cluster plates at a density of $1.0 \times 10^{5}$ cells in complete DMEM. After $24 \mathrm{~h}$ of attachment, cells were washed with PBS and stabilized in serum-free DMEM for $1 \mathrm{~h}$. Then, cells were cultured separately with and without Ti particles $(0.1 \mathrm{mg} / \mathrm{mL})$ or $\mathrm{Ti}$ particles and Ad-siTNF $\alpha$-BMP-2. After $24 \mathrm{~h}$ of incubation, control CM (cont CM), CM with Ti particles (Ti CM), and CM with Ti particles and Ad-siTNF $\alpha$-BMP-2 (Ti-ad CM) were collected, centrifuged to remove cell debris, if any, and stored at $-20^{\circ} \mathrm{C}$ until use. The conditioned media were made as previously described (26).

\section{RNA isolation and real-time RT-PCR}

Total RNA was extracted using Trizol (Invitrogen, USA) according to the manufacturer's instructions. The $260 / 280 \mathrm{~nm}$ absorbance ratio was measured for verification of RNA purity (NanoDrop, USA). First-strand cDNA was synthesized with $2 \mu \mathrm{g}$ total RNA (Fermentas, Canada), and one-tenth of the cDNA was used for each PCR mixture containing EXPRESS SYBR Green (TaKaRa, Japan) and PCR Supermix (Fermentas). The reaction was subjected to a 40 -cycle amplification at $95^{\circ} \mathrm{C}$ for $30 \mathrm{~s}$, at $95^{\circ} \mathrm{C}$ for $5 \mathrm{~s}$, and at $60^{\circ} \mathrm{C}$ for $30 \mathrm{~s}$. Relative mRNA expression of selected genes was normalized to GAPDH and quantified using the $\triangle \Delta C T$ method. The sequences of the PCR primers are listed in Table 1. 
Table 1. Primers for real-time RT-PCR.

\begin{tabular}{lcc}
\hline Target & Forward primer $\left(5^{\prime} \rightarrow 3^{\prime}\right)$ & Reverse primer $\left(3^{\prime} \rightarrow 5^{\prime}\right)$ \\
\hline TNF- $\alpha$ & TCTTCTCATTCCTGCTTGTG & ACTTGGTGGTTTGCTACG \\
IL-6 & TCCATCCAGTTGCCTTCTTG & TTTCTCATTTCCACGATTTCCC \\
IL-1 $1 \beta$ & ATCTCGCAGCAGCACATC & CAGCAGGTTATCATCATCATCC \\
BMP-2 & TTGTATGTGGACTTCAGTGATGTG & AGTTCAGTGGTAGCAAGG \\
GADPH & TCAACGGCACAGTCAAGG & ACTCCACGACATACTCAGC \\
RANKL & CAGGAGGATGAAACAAGCC & GCAGCATTGATGGTGAGG \\
\hline
\end{tabular}

\section{Protein isolation and Western blotting}

Cells were lysed in RIPA buffer (20 mM Tris- $\mathrm{HCl}, \mathrm{pH}$ 7.5, $200 \mathrm{mM} \mathrm{NaCl}, 1 \%$ Triton X-100, $1 \mathrm{mM}$ dithiothreitol) containing protease inhibitor cocktail (Roche, Switzerland). Protein concentration was measured with a bicinchoninic acid protein quantitation kit (Biovision, USA) following the manufacturer's instructions. Total protein was subjected to SDS-polyacrylamide gel electrophoresis and transferred to a PVDF membrane. The blot was probed with anti-TNF- $\alpha$ (Cell Signaling Technology, USA) and anti-BMP-2 (Abcam, England) primary antibodies. Anti- $\beta$-actin (CoWin Biotech, USA) was used as a loading control. Subsequently, the blots were washed in TBST $(10 \mathrm{mM}$ Tris- $\mathrm{HCl}, 50 \mathrm{mM}$ $\mathrm{NaCl}, 0.25 \%$ Tween 20 ) and incubated with secondary antibody. The presence of target proteins was detected using enhanced chemiluminescence reagents (Millipore Corp., USA).

\section{Alkaline phosphatase (ALP) activity assay}

ALP activity was measured with the QuantiChrom ${ }^{\mathrm{TM}}$ Alkaline Phosphatase Assay Kit (BioAssay Systems, USA). Briefly, the culture medium was removed. Cells were rinsed twice with PBS and lysed in $150 \mu \mathrm{L} /$ well RIPA buffer. Lysates were harvested, and clarified by centrifugation at $12,000 \mathrm{~g}$ at $4^{\circ} \mathrm{C}$ for $10 \mathrm{~min}$. The supernatants were incubated with $3.7 \mathrm{mM}$ 4-nitrophenyl phosphate in $100 \mathrm{mM}$ diethanolamine, $\mathrm{pH} 9.8$, containing $0.1 \%$ Triton $\mathrm{X}-100$ at $37^{\circ} \mathrm{C}$ for $5 \mathrm{~min}$. The amount of released 4nitrophenolate was determined photometrically at $405 \mathrm{~nm}$. Enzyme activity was calculated according to the manufacturer's recommendations.

\section{ELISA}

RAW264.7 cells were incubated with $\mathrm{Ti}$ particles $(0.1 \mathrm{mg} / \mathrm{mL})$ for $24 \mathrm{~h}$. Ti CM was collected to determine the concentration of TNF- $\alpha$. A mouse TNF- $\alpha$ ELISA kit (AMEKO, USA) was used for quantitative measurement following the manufacturer's recommendations.

\section{Statistical analysis}

Data are reported as means \pm SE for at least triplicate determinations. Differences between groups were analyzed using analysis of variance. Statistical significance was defined as $\mathrm{P}<0.05$. Statistical analyses were performed using SPSS version 17.0 (IBM, USA).

\section{Results}

\section{Effects of Ad-siTNF $\alpha-B M P-2$ and Ti particles on MC3T3-E1 viability}

Cell viability shown by MTT [3-(4,5-dimethylthiazol-2yl)-2,5-diphenyltetrazolium bromide] assay was not significantly different among RAW264.7 and MC3T3-E1 cells treated with different multiplicity of infection (MOI) of Ad-siTNF $\alpha$-BMP-2 (30, 50, and $70 \mathrm{MOI})$ for $48 \mathrm{~h}$ (Figure $1 \mathrm{~A}$ and $\mathrm{B}$ ). Furthermore, $0.1 \mathrm{mg} / \mathrm{mL}$ Ti particles and 50 MOI Ad-siTNF $\alpha$-BMP-2 made no difference in the viability of RAW264.7 cells at each time point (Figure 1C). Similarly, $50 \mathrm{MOI}$ Ad-siTNF $\alpha$-BMP-2 had no effect on the viability of MC3T3-E1 cells (Figure 1D). The results suggested that both Ti particles and Ad-siTNF $\alpha$-BMP-2 were not toxic to RAW264.7 cells, and Ad-siTNF $\alpha$-BMP-2 was not toxic to MC3T3-E1 cells.

\section{Effects of suppression of Ad-siTNF $\alpha$-BMP-2 on Ti particle-induced inflammatory factor}

Detection showed that the expression of TNF- $\alpha$ by real-time RT-PCR was significantly increased in RAW264.7 cells treated with different doses of Ti particles $(0.05,0.1,0.15 \mathrm{mg} / \mathrm{mL})$, and the result indicated that expression of TNF- $\alpha$ was highest in RAW264.7 cells treated with $0.1 \mathrm{mg} / \mathrm{mL}$ Ti particles (data not shown). We believed that $0.1 \mathrm{mg} / \mathrm{mL}$ Ti particles was the optimum dose-induced TNF- $\alpha$ expression for our experimental conditions. Our results showed that TNF- $\alpha$ mRNA expression at $50 \mathrm{MOI}$ was significantly reduced after $48 \mathrm{~h}$ (Figure 2A). The same result was observed for TNF$\alpha$ protein levels, as shown by Western blot analysis after $48 \mathrm{~h}$. Ad-siTNF $\alpha-B M P-2$ at $50 \mathrm{MOI}$ significantly reduced expression of TNF- $\alpha$ protein levels (Figure $2 \mathrm{~B}$ ). These results (Figure $2 A$ and $B$ ) confirmed that Ad-siTNF $\alpha$-BMP2 reduced TNF- $\alpha$ expression in RAW264.7 cells treated with $0.1 \mathrm{mg} / \mathrm{mL}$ Ti particles.

We also detected inflammatory factors IL-1 $\beta$ and IL-6. The results showed that downregulation of TNF- $\alpha$ mRNA reduced mRNA expression of inflammatory cytokines such as IL-6 (Figure $2 \mathrm{C}$ ) and IL-1 $\beta$ (Figure $2 \mathrm{D}$ ). It is suggested that TNF- $\alpha$ can promote IL- 6 and IL- $1 \beta$ mRNA expression.

Detection of TNF- $\alpha$ protein levels by ELISA was performed for assessment of RAW264.7 cells treated 

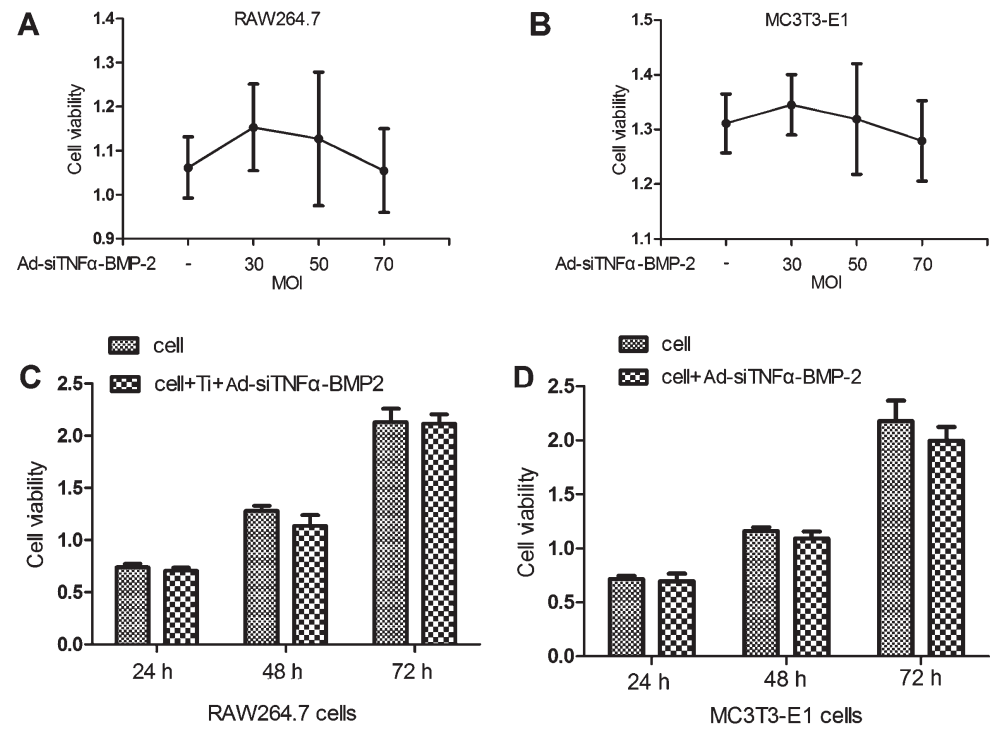

Figure 1. Effect of Ad-siTNF $\alpha$-BMP-2 on cell viability. A, RAW264.7 cells $(A)$ and MC3T3-E1 cells $(B)$ were treated with different MOls of $\mathrm{Ad}$ siTNF $\alpha$-BMP-2 for 48 h. $C$, RAW264.7 cells were treated with Ti and $50 \mathrm{MOI}$ Ad-siTNF $\alpha$-BMP-2 for 24-72 h. $D$, MC3T3-E1 cells were treated with 50 MOI Ad-siTNF $\alpha$-BMP-2 for 24-72 h. The cellular activity was estimated by MTT assay. Data are reported as means \pm SD. MOI: multiplicity of infection.

with $0.1 \mathrm{mg} / \mathrm{mL}$ Ti particles or a combination of $0.1 \mathrm{mg} /$ $\mathrm{mL}$ Ti particles and 50 MOI Ad-siTNF $\alpha$-BMP-2 for $24 \mathrm{~h}$ (Figure 2E).

\section{BMP-2 expression in MC3T3-E1 cells treated with Ad- siTNF $\alpha$-BMP-2}

We detected the expression of BMP-2 mRNA by realtime PCR, which was significantly increased in MC3T3-E1 cells treated with different $\mathrm{MOI}(30,50$, and 70). Our results showed that the MOI of Ad-siTNF $\alpha$-BMP- 2 was determined to be 50 (Figure $3 \mathrm{~A}$ ). The same result was shown for TNF- $\alpha$ protein levels by the detection of Western blots after $48 \mathrm{~h}$ (Figure 3C). Expression of BMP-2 was analyzed at 2, 4, and 6 days in MC3T3-E1 cells treated with $50 \mathrm{MOI}$ Ad-siTNF $\alpha$-BMP-2 by real-time RT-PCR (Figure 3B).

Induction of osteoblast differentiation and inhibition of osteoclastogenesis by transduction of MC3T3-E1 cells with Ad-siTNF $\alpha$-BMP-2 and different conditioned media

ALP activity, a marker of the early period of osteoblastic differentiation, was assessed at 2, 4, and 6 days in MC3T3E1 cells treated with Ad-siTNF $\alpha$-BMP-2 using an ALP kit (Figure 4A). The result indicated that Ad-siTNF $\alpha-B M P-2$ could induce osteoblast differentiation.

Furthermore, Ad-siTNF $\alpha$-BMP-2 induced osteoblast differentiation when treated with different $\mathrm{CM}$ (cont $\mathrm{CM}$, Ti $\mathrm{CM}$, or Ti-ad CM), and assessed by levels of ALP activity (Figure 4B). The results suggest that Ad-siTNF $\alpha$-BMP-2 might compensate Ti particle-induced osteolysis through promoting osteoblast differentiation in vivo.

RANKL is a member of the TNF family that is essential for osteoclastogenesis (30). We detected expression of RANKL mRNA in MC3T3-E1 cells treated with different
CM (cont CM, Ti CM, and Ti-ad CM) by real-time PCR (Figure 4C). The result indicated that Ad-siTNF $\alpha$-BMP-2 might inhibit Ti particle-induced osteoclastogenesis.

\section{Discussion}

Currently, there is no effective treatment for aseptic joint loosening apart from reoperation. Reoperated patients suffer a serious physical and psychological trauma and economic burden; in addition, there are high risks of operation and of subsequent multiple perioperative complications for elderly patients who undergo revision. Subsequently, there is a research focus on approaches for taking advantage of nonsurgical methods to cure aseptic joint loosening. However, there is still no recognized effective treatment because the mechanism of aseptic joint loosening is not completely clear. Despite all this, metal particle-induced proinflammatory cytokines such as IL-1 $\beta$ and TNF- $\alpha$ are considered to be important factors for stimulating osteoclastogenesis.

Cytokines such as TNF- $\alpha$, IL- $1 \beta$, and IL- 6 are involved in osteoclastogenesis through induced RANKL expression in osteoblasts. In this study, Ad-siTNF $\alpha$-BMP-2 could inhibit Ti particles induced to increase TNF- $\alpha$ in macrophages and simultaneously could also downregulate IL-1 $\beta$ and IL-6 expression in cultures with $\mathrm{Ti}$ particles. Our results showed that Ad-siTNF $\alpha-B M P-2$ effectively reduced expression of RANKL in MC3T3-E1 cells by downregulating expression of these proinflammatory cytokines from RAW264.7 cells in response to $\mathrm{Ti}$ particles. Downregulation of TNF- $\alpha$ levels was important for expression of RANKL, which was critical for osteoclast differentiation and function. Furthermore, TNF- $\alpha$ and RANKL support osteoclast survival $(31,32)$. Ad-siTNF $\alpha-$ BMP-2 directly and indirectly downregulated TNF- $\alpha$ and 

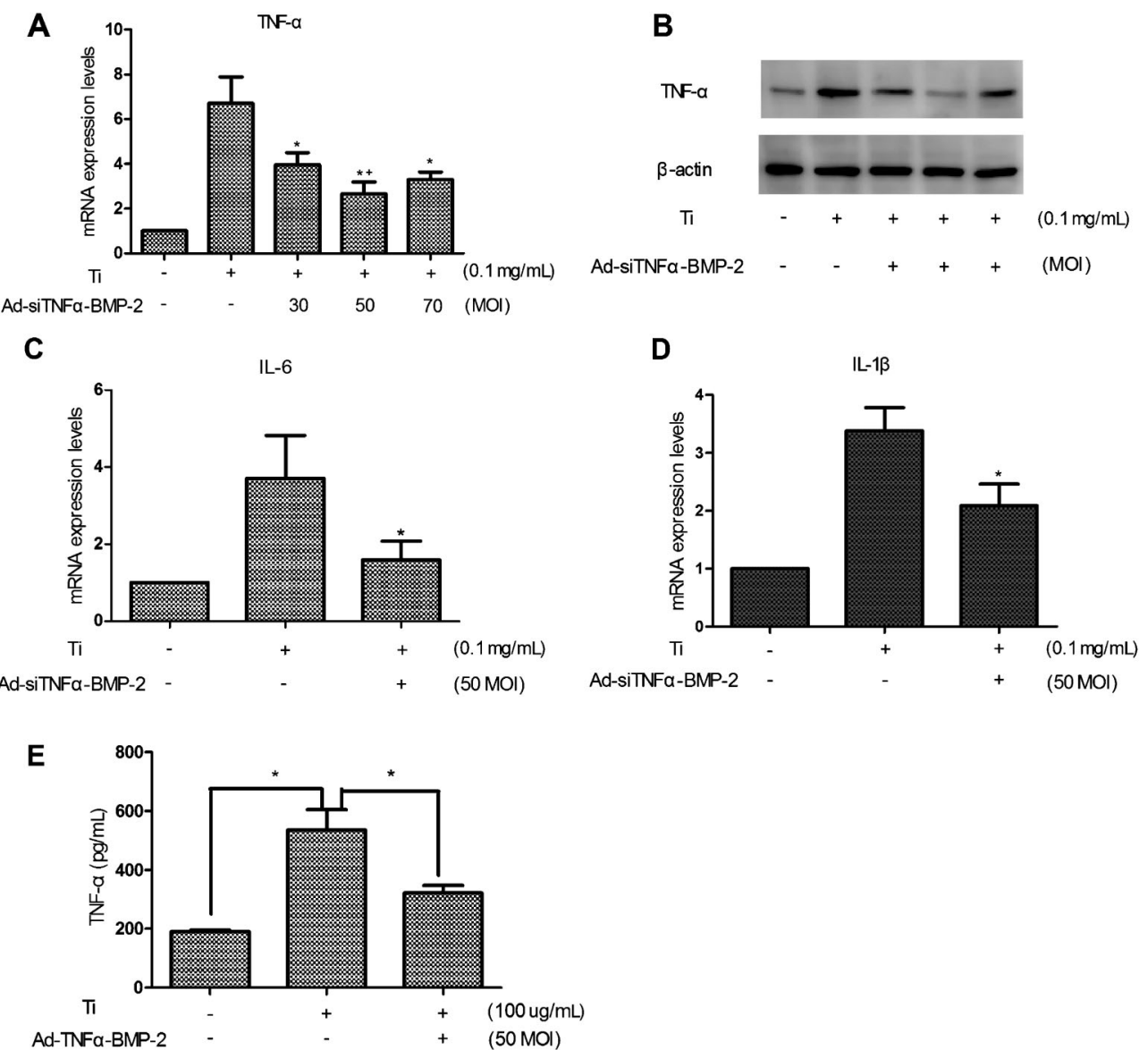

Figure 2. Suppression effects of Ad-siTNF $\alpha$-BMP-2 on titanium particle-induced inflammatory factor. A, RAW264.7 cells were plated on 6well cluster plates at a density of $4 \times 10^{5}$ cells/well. After $24 \mathrm{~h}$, RAW264.7 cells were treated with or without Ti particles in the presence or absence of Ad-siTNF $\alpha$-BMP-2 for $48 \mathrm{~h}$. There was a significant reduction of TNF- $\alpha$ mRNA expression at 50 MOI . $B$, TNF- $\alpha$ protein levels detected by Western blot after $48 \mathrm{~h}$. There was significant reduction of IL-6 $(C)$ and IL-1 $\beta(D)$ mRNA expression by Ad-siTNF $\alpha$-BMP-2 at 50 MOI. E, TNF- $\alpha$ protein levels detected by ELISA when treated with $0.1 \mathrm{mg} / \mathrm{mL}$ Ti particles or a combination of $0.1 \mathrm{mg} / \mathrm{mL}$ Ti particles and 50 $\mathrm{MOI}$ Ad-siTNF $\alpha$-BMP-2 for $24 \mathrm{~h}$. Data are reported as means \pm SD. Similar results were obtained in three independent experiments. MOI: multiplicity of infection. ${ }^{*} \mathrm{P}<0.05$, compared to the cultures with Ti particles only; ${ }^{+} \mathrm{P}<0.05$, compared to $30 \mathrm{MOI}$ (one-way ANOVA).

RANKL expression in our experiment. It is speculated that Ad-siTNF $\alpha$-BMP-2 might reduce Ti particle-induced bone resorption.

ALP activity is a marker of the early period of osteoblastic differentiation. In our study, Ad-siTNF $\alpha$ BMP-2 promoted pro-osteoblast differentiation into osteoblasts, which contributed to the increased number of osteoblasts and bone formation. Furthermore, promotion of osteoblast differentiation reduced RANKL expression and inhibited the ability of the cells to support osteoclast differentiation $(18,19)$; osteoblast expression of the RANKL/OPG ratio was much higher in less mature osteoblasts than in mature ones (19). Simultaneously, TNF- $\alpha$ induced apoptosis much easier in less mature osteoblasts than in mature ones (32). Hence, Ad-siTNF $\alpha$ BMP-2 may promote osteoblast differentiation, contribute to osteoclast differentiation inhibition, and increase bone formation.

TNF- $\alpha$, IL-6, and IL-1 $\beta$ can inhibit osteoblast differentiation (15-17) and TNF- $\alpha$ has been shown to inhibit BMP-2 signaling pathways (24-26). In this study, macrophages challenged in culture with media containing titanium particles (Ti CM) inhibited Ad-siTNF $\alpha$-BMP-2induced osteoblast differentiation. Ad-siTNF $\alpha-B M P-2$ induced osteoblast differentiation in macrophage cultures in conditioned medium including $\mathrm{Ti}$ particles and $\mathrm{Ad}$ siTNF $\alpha$-BMP-2 (Ti-ad CM). The results suggested that Ad-siTNF $\alpha$-BMP-2 was expected to induce osteoblast differentiation in a cell model of wear particle-induced inflammation, which was an essential part of bone formation that compensated resorbed bone matrix to maintain its structural integrity.

Orthopedic gene therapy had its origins in the early 1990 s in attempts to deliver genes to joints $(33,34)$. The aim 
A

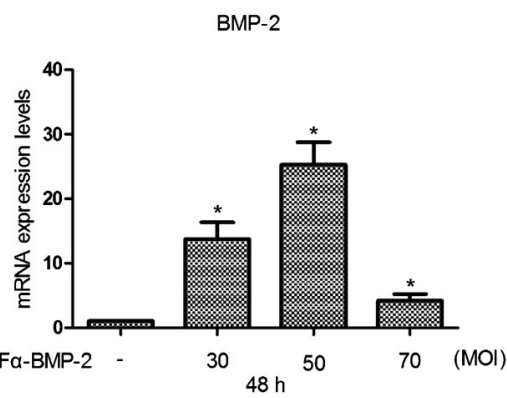

B

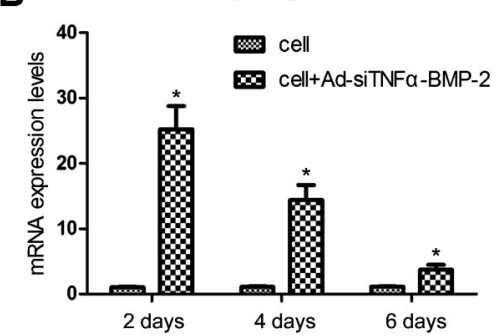

\section{c}

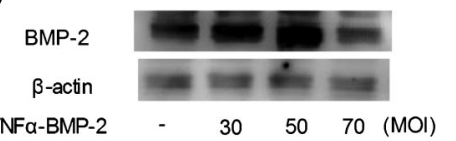

Figure 3. BMP-2 expression in MC3T3-E1 treated with AdsiTNF $\alpha$-BMP-2. A, MC3T3-E1 cells were plated on 6 -well cluster plates at a density of $4 \times 10^{5}$ cells/well. After $24 \mathrm{~h}$, MC3T3-E1 cells were treated with Ad-siTNF $\alpha$-BMP- 2 for $48 \mathrm{~h}$. There was a significant increase of BMP-2 mRNA expression. $B$, Expression of BMP-2 was analyzed at 2, 4, and 6 days in MC3T3-E1 cells treated with $50 \mathrm{MOI}$ Ad-siTNF $\alpha$-BMP-2. C, BMP-2 protein levels detected by Western blot after $48 \mathrm{~h}$. Data are reported as means \pm SD. Similar results were obtained in three independent experiments. MOI: multiplicity of infection. ${ }^{*} \mathrm{P}<0.01$, compared to control (one-way ANOVA).

of the present study was to design intra- and periarticular tissues that can promote synthesis of anti-arthritic gene products, thereby providing a sustained, local therapy for individual arthritic joints. This approach is attractive because joints are discrete, accessible cavities that can be readily injected. Interference RNA is an almost standard method for the knockdown of any target gene of interest in vitro, exploring a naturally occurring catalytic mechanism. The downregulation of pathologically relevant genes that are aberrantly expressed in a given disease will offer novel therapeutic approaches. siRNA therapeutics has developed rapidly, and already there are clinical trials ongoing or planned. Meanwhile, BMP-2 is approved for clinical use to help induce osteogenesis (35-37). The long journey from the identification of BMP-2 in demineralized bone fractions to US Food and Drug Administration approval for use in a singular orthopedic application has been completed. It has been demonstrated to be safe, efficacious, and costeffective, leading to increased patient satisfaction and
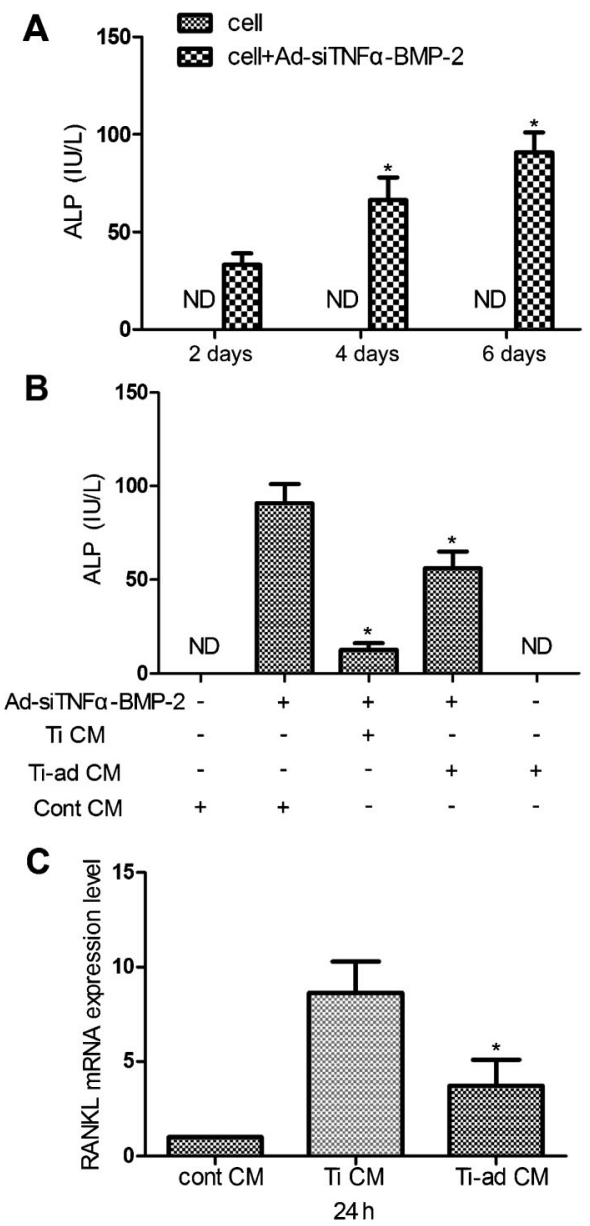

Figure 4. Induction of osteoblast differentiation evaluated by a combination of treatment with conditioned medium (CM; Ti CM and Ti-ad CM) and Ad-siTNF $\alpha$-BMP-2. Inhibition of RANKL mRNA expression in MC3T3-E1 cells was evaluated by a combination of treatment with $\mathrm{CM}$ ( $\mathrm{Ti} \mathrm{CM}$ and Ti-ad $\mathrm{CM})$. Data are reported as means $\pm S D$. Similar results were obtained in three independent experiments. A, MC3T3-E1 cells were plated on 24-well cluster plates at a density of $1 \times 10^{5}$ cells/well. After $24 \mathrm{~h}$, MC3T3-E1 cells were treated with Ad-siTNF $\alpha$-BMP-2 (50 MOI), ALP activity levels were assessed for 2-6 days. ${ }^{*} P<0.05$, compared to the treatment with Ad-siTNF $\alpha$-BMP-2 (50 MOI) at 2 days. B, ALP activity was assessed in MC3T3-E1 cells treated with Ad-siTNF $\alpha$-BMP-2 (50 $\mathrm{MOI}$ ) and $\mathrm{CM}$ [cont (control) $\mathrm{CM}, \mathrm{Ti} \mathrm{CM}$ and Ti-ad CM] at 6 days. ${ }^{*} \mathrm{P}<0.05$, compared to the treatment with a combination cont $\mathrm{CM}$ and Ad-siTNF $\alpha$-BMP-2. C, MC3T3-E1 cells were treated with CM (cont $\mathrm{CM}, \mathrm{Ti} \mathrm{CM}$ and $\mathrm{Ti}$-ad $\mathrm{CM}$ ) for $24 \mathrm{~h}$. RANKL mRNA expression was assessed by real-time RT-PCR. MOI: multiplicity of infection, ND: not detected. ${ }^{*} \mathrm{P}<0.05$, compared to the treatment with Ti CM (one-way ANOVA).

improved clinical outcomes (38). Therefore, Ad-siTNF $\alpha$ BMP-2 may provide a promising therapeutic approach for the treatment of periprosthetic osteolysis.

Our results also emphasized the need for more effective treatment methods. Further evidence of the effect of Ad-siTNF $\alpha$-BMP-2 on particle-induced osteolysis 
is required in in vivo experiments on animal models. This would involve the creation of an animal model of aseptic loosening, and would then involve the local administration of an intra-articular injection of recombinant adenovirus in order to detect the effect of recombinant adenovirus on $\mathrm{Ti}$ particle-induced proinflammatory cytokine expression and periprosthetic osteolysis. Our data may aid in the

\section{References}

1. Harris WH. The problem is osteolysis. Clin Orthop Relat Res 1995; 311: 46-53.

2. Goldring SR, Clark CR, Wright TM. The problem in total joint arthroplasty: aseptic loosening. J Bone Joint Surg Am 1993; 75: 799-801.

3. Kadoya $\mathrm{Y}$, Kobayashi A, Ohashi H. Wear and osteolysis in total joint replacements. Acta Orthop Scand Suppl 1998; 278: 1-16.

4. Friedman RJ, Black J, Galante JO, Jacobs JJ, Skinner HB. Current concepts in orthopaedic biomaterials and implant fixation. Instr Course Lect 1994; 43: 233-255.

5. Harris WH. Wear and periprosthetic osteolysis: the problem. Clin Orthop Relat Res 2001; 393: 66-70, doi: 10.1097/ 00003086-200112000-00007.

6. Hallab NJ, Jacobs JJ. Biologic effects of implant debris. Bull NYU Hosp Jt Dis 2009; 67: 182-188.

7. Kaufman AM, Alabre $\mathrm{Cl}$, Rubash HE, Shanbhag AS. Human macrophage response to UHMWPE, TiAIV, $\mathrm{CoCr}$, and alumina particles: analysis of multiple cytokines using protein arrays. J Biomed Mater Res A 2008; 84: 464-474.

8. Liu F, Zhu Z, Mao Y, Liu M, Tang T, Qiu S. Inhibition of titanium particle-induced osteoclastogenesis through inactivation of NFATc1 by VIVIT peptide. Biomaterials 2009; 30: 1756-1762, doi: 10.1016/j.biomaterials.2008.12.018.

9. Shanbhag AS, Jacobs JJ, Black J, Galante JO, Glant TT. Cellular mediators secreted by interfacial membranes obtained at revision total hip arthroplasty. J Arthroplasty 1995; 10: 498-506, doi: 10.1016/S0883-5403(05)80152-4.

10. Jacobs JJ, Roebuck KA, Archibeck M, Hallab NJ, Glant TT. Osteolysis: basic science. Clin Orthop Relat Res 2001; 393: 71-77, doi: 10.1097/00003086-200112000-00008.

11. Ingham E, Fisher $\mathrm{J}$. The role of macrophages in osteolysis of total joint replacement. Biomaterials 2005; 26: 12711286, doi: 10.1016/j.biomaterials.2004.04.035.

12. Boyce BF, Li P, Yao Z, Zhang Q, Badell IR, Schwarz EM, et al. TNF-alpha and pathologic bone resorption. Keio J Med 2005; 54: 127-131, doi: 10.2302/kjm.54.127.

13. Tanaka Y, Nakayamada S, Okada Y. Osteoblasts and osteoclasts in bone remodeling and inflammation. Curr Drug Targets Inflamm Allergy 2005; 4: 325-328, doi: 10.2174/ 1568010054022015.

14. Mori T, Miyamoto $\mathrm{T}$, Yoshida $\mathrm{H}$, Asakawa M, Kawasumi M, Kobayashi T, et al. IL-1beta and TNFalpha-initiated IL-6STAT3 pathway is critical in mediating inflammatory cytokines and RANKL expression in inflammatory arthritis. Int Immunol 2011; 23: 701-712, doi: 10.1093/intimm/dxr077.

15. Hikiji H, Shin WS, Koizumi T, Takato T, Susami T, Koizumi $Y$, et al. Peroxynitrite production by TNF-alpha and IL-1beta: implication for suppression of osteoblastic differentiation. Am J Physiol Endocrinol Metab 2000; 278: E1031-E1037. continued advances in research for the prevention and/ or treatment of particle-induced osteolysis.

\section{Acknowledgments}

Research supported by the National Natural Science Foundation of China (NSFC, \#81060146).
16. Gilbert L, He X, Farmer P, Boden S, Kozlowski M, Rubin J, et al. Inhibition of osteoblast differentiation by tumor necrosis factor-alpha. Endocrinology 2000; 141: 39563964, doi: 10.1210/en.141.11.3956.

17. Peruzzi B, Cappariello A, Del Fattore A, Rucci N, De Benedetti F, Teti A. C-Src and IL-6 inhibit osteoblast differentiation and integrate IGFBP5 signalling. Nat Commun 2012; 3: 630, doi: 10.1038/ncomms1651.

18. Gori F, Hofbauer LC, Dunstan CR, Spelsberg TC, Khosla S, Riggs BL. The expression of osteoprotegerin and RANK ligand and the support of osteoclast formation by stromal-osteoblast lineage cells is developmentally regulated. Endocrinology 2000; 141: 4768-4776, doi: 10.1210/en.141.12.4768.

19. Atkins GJ, Kostakis $P$, Pan B, Farrugia A, Gronthos S, Evdokiou A, et al. RANKL expression is related to the differentiation state of human osteoblasts. J Bone Miner Res 2003; 18: 1088-1098, doi: 10.1359/jbmr.2003.18.6.1088.

20. Thomas GP, Baker SU, Eisman JA, Gardiner EM. Changing RANKL/OPG mRNA expression in differentiating murine primary osteoblasts. J Endocrinol 2001; 170: 451-460, doi: 10.1677/joe.0.1700451.

21. Yamaguchi A, Katagiri T, Ikeda T, Wozney JM, Rosen V, Wang EA, et al. Recombinant human bone morphogenetic protein-2 stimulates osteoblastic maturation and inhibits myogenic differentiation in vitro. J Cell Biol 1991; 113: 681687, doi: $10.1083 / j c b .113 .3 .681$.

22. Kang Q, Sun $M H$, Cheng H, Peng Y, Montag AG, Deyrup AT, et al. Characterization of the distinct orthotopic boneforming activity of 14 BMPs using recombinant adenovirusmediated gene delivery. Gene Ther 2004; 11: 1312-1320, doi: $10.1038 /$ sj.gt.3302298.

23. Castro-Govea Y, Cervantes-Kardasch VH, Borrego-Soto G Martinez-Rodriguez HG, Espinoza-Juarez M, Romero-Diaz $\mathrm{V}$, et al. Human bone morphogenetic protein 2-transduced mesenchymal stem cells improve bone regeneration in a model of mandible distraction surgery. J Craniofac Surg 2012; 23: 392-396, doi: 10.1097/SCS.0b013e318240fe9b.

24. Gilbert L, He X, Farmer P, Rubin J, Drissi H, van Wijnen AJ, et al. Expression of the osteoblast differentiation factor RUNX2 (Cbfa1/AML3/Pebp2alpha A) is inhibited by tumor necrosis factor-alpha. J Biol Chem 2002; 277: 2695-2701, doi: 10.1074/jbc.M106339200.

25. Kaneki H, Guo R, Chen D, Yao Z, Schwarz EM, Zhang YE, et al. Tumor necrosis factor promotes Runx2 degradation through up-regulation of Smurf1 and Smurf2 in osteoblasts. J Biol Chem 2006; 281: 4326-4333, doi: 10.1074/jbc.M509430200.

26. Lee SS, Sharma AR, Choi BS, Jung JS, Chang JD, Park S, et al. The effect of TNFalpha secreted from macrophages activated by titanium particles on osteogenic activity regulated by WNT/BMP signaling in osteoprogenitor cells. 
Biomaterials 2012; 33: 4251-4263, doi: 10.1016/j.biomaterials.2012.03.005

27. Rakshit DS, Ly K, Sengupta TK, Nestor BJ, Sculco TP, Ivashkiv LB, et al. Wear debris inhibition of anti-osteoclastogenic signaling by interleukin-6 and interferon-gamma. Mechanistic insights and implications for periprosthetic osteolysis. J Bone Joint Surg Am 2006; 88: 788-799, doi: 10.2106/JBJS.E.00711.

28. Anderson RD, Haskell RE, Xia H, Roessler BJ, Davidson $\mathrm{BL}$. A simple method for the rapid generation of recombinant adenovirus vectors. Gene Ther 2000; 7: 1034-1038, doi: 10.1038/sj.gt.3301197.

29. Palmer GD, Gouze E, Gouze JN, Betz OB, Evans CH, Ghivizzani SC. Gene transfer to articular chondrocytes with recombinant adenovirus. Methods Mol Biol 2003; 215: 235-246.

30. Nakagawa N, Kinosaki M, Yamaguchi K, Shima N, Yasuda $\mathrm{H}$, Yano $\mathrm{K}$, et al. RANK is the essential signaling receptor for osteoclast differentiation factor in osteoclastogenesis. Biochem Biophys Res Commun 1998; 253: 395-400, doi: 10.1006/bbrc. 1998.9788.

31. Blair HC, Robinson LJ, Zaidi M. Osteoclast signalling pathways. Biochem Biophys Res Commun 2005; 328: 728-738, doi: 10.1016/j.bbrc.2004.11.077.

32. Xing L, Boyce BF. Regulation of apoptosis in osteoclasts and osteoblastic cells. Biochem Biophys Res Commun 2005; 328: 709-720, doi: 10.1016/j.bbrc.2004.11.072.

33. Bandara G, Robbins PD, Georgescu HI, Mueller GM, Glorioso JC, Evans $\mathrm{CH}$. Gene transfer to synoviocytes: prospects for gene treatment of arthritis. DNA Cell Biol 1992; 11: 227-231, doi: 10.1089/dna.1992.11.227.

34. Bandara G, Mueller GM, Galea-Lauri J, Tindal MH, Georgescu HI, Suchanek MK, et al. Intraarticular expression of biologically active interleukin 1-receptor-antagonist protein by ex vivo gene transfer. Proc Natl Acad Sci U S A 1993; 90: 10764-10768, doi: 10.1073/pnas.90.22.10764.

35. Lee K, Silva EA, Mooney DJ. Growth factor delivery-based tissue engineering: general approaches and a review of recent developments. J R Soc Interface 2011; 8: 153-170, doi: 10.1098/rsif.2010.0223.

36. Salgado AJ, Coutinho OP, Reis RL. Bone tissue engineering: state of the art and future trends. Macromol Biosci 2004; 4: 743-765, doi: 10.1002/mabi.200400026.

37. Yilgor P, Hasirci N, Hasirci V. Sequential BMP-2/BMP-7 delivery from polyester nanocapsules. J Biomed Mater Res A 2010; 93: 528-536.

38. Khan SN, Lane JM. The use of recombinant human bone morphogenetic protein-2 (rhBMP-2) in orthopaedic applications. Expert Opin Biol Ther 2004; 4: 741-748, doi: 10.1517| 14712598.4.5.741. 